\title{
THE UTILIZATION OF BLACK RICE YEAST AND ITS PHYSIOLOGICAL EFFECTS ON MICE (Mus musculus) WHICH ARE EXPOSED TO TYPE 2 DIABETES MELLITUS
}

\author{
R. Agustini ${ }^{1,}$, I. G. M. Sanjaya ${ }^{1}$, N. Herdyastuti ${ }^{1}$ and A. Sabarudin ${ }^{2}$ \\ ${ }^{1}$ Department of Chemistry, Universitas Negeri Surabaya, Surabaya-60231, Indonesia \\ ${ }^{2}$ Department of Chemistry, Brawijaya University, Malang-65145, Indonesia \\ ${ }^{\otimes}$ Corresponding Author: rudianaagustini@unesa.ac.id
}

\begin{abstract}
Black rice is widely available in nature and rich in nutrients. The research aimed at utilizing yeast-black rice (yeast$\mathrm{BR}$ ) and its physiological effects on mice exposed to type 2 diabetes mellitus (type $2 \mathrm{DM}$ ). Mice were induced by high fat and fructose diet then classified and treated as follows: 1) DM + yeast-BR; 2) DM + glibenclamide; 3) DM; and 4) Non-DM. All groups were given commercial feed. The treatment was given for 10 days and then tested for the physiological effects (decreasing blood glucose levels, the volume of drinking water and urine, diet, and absorption of chromium by the small intestine). The results show 1) the highest reduction in blood glucose levels was treated with $\mathrm{DM}+$ yeast-BR; 2) the largest volume of drinking water and urine was in the DM + yeast-BR group; 3 ) absorbed diet in the DM + yeast-BR group was lower than the non-DM or DM + glibenclamide, but higher than the DM group; 4) The largest percentage of chromium absorbed by the small intestine was in the DM + yeastBR group; 5) There was a correlation between reduction in blood glucose levels and the percentage of absorbed chromium in the DM + yeast-BR feed, but no correlation between reduction in blood glucose levels and the percentage of chromium absorbed in the Non-DM.
\end{abstract}

Keywords: Black Rice Yeast, Type 2 Diabetes Mellitus, Absorption of Chromium (III), Physiology Effect, Mice RASĀYAN J. Chem., Vol. 14, No.2, 2021

\section{INTRODUCTION}

Yeast or better known as Saccharomyces cerevisiae is a group of single-cell fungi. This yeast can be grown in various media containing carbohydrates. One of the ingredients that can be used to grow yeast is black rice. Black rice contains nutrients including fiber, protein, vitamins, minerals that are beneficial for human health and anthocyanins which are known as antioxidants. ${ }^{1}$ Yeast in black rice media undergoes fermentation. The yeast fermentation process in black rice affects its bioactive component, specifically an enhancement in cytotoxic activity and a reduction in antioxidant activity. ${ }^{1,2}$ Extracted yeast that has been grown in black rice is known as black rice yeast (yeast-BR). The study shows that chromium in yeast improves glucose tolerance in diabetics. DM is a metabolic disorder in which $\beta$-pancreatic cells cannot produce insulin normally or the body's cells are unable to use the insulin produced effectively. This hormone is known to play an important role in regulating blood glucose levels. Someone who has blood glucose levels above normal as a marker of suffering from hyperglycemia. Hyperglycemia has the potential to cause abnormalities in other organs, including high blood pressure and a decreased immune system. According to the Indonesian Ministry of Health, DM is categorized as a chronic degenerative disease characterized by an increase in fasting blood sugar levels above normal levels (above $120 \mathrm{mg} \mathrm{dl}$ ). The chronic increases in blood sugar levels will be accompanied by various metabolic disorders. This metabolic disorder is related to hormonal disorders which in turn can lead to various complications in various organs of the body. ${ }^{3} \mathrm{DM}$ is a big health problem, indicated by the prevalence rate of DM sufferers globally in 2011 was reaching up to 366 million people. In 2030, it is predicted that the cases will increase to 552 million. Of the cases, the data show that most DM patients were $40-65$ years old, $75 \%$ of DM patients were 40-59 years old. ${ }^{4}$ Type 2 DM sufferers experience interference with insulin hormone receptors in blood cells. In patients with this type of DM, the insulin hormone is produced properly but the receptors on the blood cells are not sufficiently supportive and insulin resistance will occur. So, in this 
condition, insulin levels can be normal, low, or high, but insulin is lacking or may not function in metabolism, glucose levels in the blood remain high, causing hyperglycemia. Type $2 \mathrm{DM}$ is known to be the type of DM that is most commonly found in society.

The role of insulin in its activity is influenced by chromium. Chromium is classified as a trace mineral that functions in metabolism. ${ }^{5}$ This compound can be obtained from food consumed daily. In terms of its valence number, there are several differences in chromium, but chromium with valence III or chromium (III) is known to be the most stable. This trivalent chromium food ingredient is in small amounts, 1-2 $\mu$ grams $^{6}$, safe and non-toxic to the body. ${ }^{7}$ Several studies have revealed a relationship between chromium, insulin, and DM in glucose metabolism. Blood glucose tolerance in DM 2 patients can be improved by chromium supplementation. ${ }^{8}$ The US Diet stipulates that daily consumption of chromium is $50-200 \mathrm{mg}$ for adults ${ }^{9}, 2 \%$ of which can be absorbed by the small intestine and the rest will be excreted with feces. The intake of amino acids, vitamin $\mathrm{C}$ and niacin affects the absorption of chromium (III) by the small intestine.

The role of chromium in metabolism is to assist the entry of glucose in the body's cells by interacting with a molecule that has a low weight, namely LMWCr. ${ }^{10}$ This interaction will activate insulin and contribute to the insulin signal strengthening system. Insulin inactive form will activate tyrosine kinase. Chromium is also known to inhibit phosphotyrosine phosphatase, an enzyme that releases phosphate from insulin receptors, resulting in decreased insulin sensitivity. The balance between kinase and phosphatase activity can facilitate the role of insulin in moving glucose rapidly into cells. ${ }^{11}$ Research has been conducted to examine the interaction of chromium (III) with GLUT 1 which is important in facilitating glucose transport into cells. These interactions are studied using computational chemical methods that had involved modeling, computation and molecular docking. The result shows that Glucose transporter 1 (GLUT 1) with chromium (III) ion has a stable interaction. This interaction is predicted to increase the reactivity of GLUT 1 in transporting glucose into the cell because the surface area of $\sigma$ GLUT 1 becomes 23 (22.64144 to be precise) times greater, from $18,750 \AA 2$ to $424,527 \AA 2 .{ }^{12}$ The chromium activity model as anti-DM 2 produced from this computational simulation needs to be tested empirically using experimental mice indicated with type 2 diabetes by feeding the ingredients containing chromium, namely yeast-black rice (Yeast-BR). This empirical experiment can be used to explain the effect of chromium (III) on the physiological effects and reduction of blood glucose levels in experimental animals. The physiological effects include the volume of urine produced by mice with type 2 diabetes after treatment with yeast-BR, water intake (volume of water drunk), small intestine absorbed diet, excretion of feces, $\%$ absorbed chromium.

\section{Material and Methods}

\section{EXPERIMENTAL}

\section{Black Rice Preparation As A Medium for Yeast Growth}

The first step is the process of making black rice flour. $100 \mathrm{~g}$ of flour dissolved in $300 \mathrm{~mL}$ of distilled water, then heated until it forms a gel and cools. The gelatinized flour was then added with $5 \mathrm{~mL} \alpha-$ amylase and commercial glucoamylase enzymes, each of which was incubated for 12 hours at $27^{\circ} \mathrm{C}$ to produce hydrolyzate which was used as yeast growth medium. This process is carried out to break down the black rice starch into simpler molecules so that it is easily metabolized by yeast.

\section{Yeast Production using Black Rice Media}

$100 \mathrm{~g}$ of yeast (commercial yeast bakery) was added to black rice hydrolyzate and fermented for 10 days at $27^{\circ} \mathrm{C}$ and then dried using a freeze-dryer. The product from the freeze-dryer is yeast-BR (yeast-black rice), which is ready to be tested on mice.

\section{Treatment of Yeast-BR in Mice}

Treatment of yeast-BR in mice consisted of 4 stages: (1) the adaptation stage, (2) induction of a high fat and fructose diet, (3) treatment with the test material and (4) measuring the physiological effects on the mice. In the adaptation phase: male mice aged \pm 4 weeks with a bodyweight of 20-24 grams were adapted for 7 days. The adapted mice were selected randomly (simple random sampling) and grouped into 4 groups, namely the test group, control of positive, control of negative, and control of normal. The test 
RASĀYAN J. Chem.

Vol. 14 | No. 3 |1507-1513| July - September | 2021

group, control of positive, and control of negative was induced by a high-fat diet and fructose for 10 days so that they were exposed to type 2 diabetes (BGL> $150 \mathrm{mg} / \mathrm{dL}$.), control of positive (DM + glibenclamide + commercial feed, control of negative (DM + commercial feed, and control of normal (Non-DM + commercial feed). The treatment was given for 10 days and tested for the decrease in blood glucose levels (BGL), drinking water volume and urine, diet and absorption of chromium by the small intestine. BGL was measured using a OneTouch blood glucose meter.

\section{Determination of Chromium (III)}

Chromium measurement was carried out through the cyclic voltammetry method using a voltammogram. ${ }^{13}$ The initial stage carried out was the preparation of a standard solution, namely a solution of $\mathrm{CrCl}_{3} \cdot 6 \mathrm{H}_{2} \mathrm{O}$ (sigma, pro analysis) in various concentrations of 5, 10, 20, 40, and $80 \mathrm{ppm}$. Each standard solution was measured using a voltammeter, Silica-Carbon electrode, and a scanning speed of 50 $\mathrm{mV} / \mathrm{second}$. The measurement produced a voltammogram which was then analyzed using the Origin-Pro program. The current strength obtained from the analysis using Origin-Pro software was mapped with the concentration of standard solutions and the linear regression equation was determined $y=a+b x$. The sample solution being tested was determined by the amount of current as well, then it was entered into the regression equation obtained and the chromium content in the sample would be obtained. Chromium tested included \% chromium in total diet (commercial feed diet and yeast-BR diet), urine, and feces.

\section{Determination of chromium (III) levels of commercial feed and yeast-BR}

Commercial feed in the form of pellets as much as 10 grams was put into a porcelain container and put in the oven for 4 hours at the temperature of $750^{\circ} \mathrm{C}$ until ash was formed. The ash was then dissolved with $1 \mathrm{~mL}$ of concentrated $\mathrm{HCl}$ and $\mathrm{HNO} 3$ and allowed to stand for \pm 15 minutes, and then added with $25 \mathrm{~mL}$ of aquademin. $10 \mathrm{~mL}$ of the solution were taken, $5 \mathrm{~mL}$ of citrate buffer $(\mathrm{pH} 3)$ was added and $10 \mathrm{~mL}$ of $0.1 \mathrm{~N} \mathrm{KCl}$. The strong current was measured using a voltameter and analyzed with the OriginPro 7.0 program. The same procedure was carried out on yeast-BR.

\section{Determination of Chromium (III) Levels in Mice Feces}

10 grams of feces mice was put into a porcelain crucible and then furnaced for 4 hours at the temperature of $750^{\circ} \mathrm{C}$ until they turned into ash, and then dissolved with $1 \mathrm{~mL}$ of concentrated $\mathrm{HCl}$ and concentrated HNO3. The mixture was left aside for \pm 15 minutes and then dissolved with $25 \mathrm{~mL}$ of aquademine. $10 \mathrm{~mL}$ were taken and added citrate of buffer $\mathrm{pH} 3$ as much $5 \mathrm{~mL}$ and $10 \mathrm{~mL} \mathrm{KCl}$ $0.1 \mathrm{~N}$. The strong current was measured using voltameter and analyzed with the OriginPro 7.0 program. The result was put into the linear regression equation of the chromium (III) standard solution, and chromium (III) was obtained in the mice feces.

\section{Determination of Chromium (III) Levels in Mice Urine}

$1 \mathrm{~mL}$ of urine mice was diluted with aquademin in a $10 \mathrm{~mL}$ volumetric flask until the limit mark was added and buffer citrate $\mathrm{pH} 3$ as much $5 \mathrm{~mL}, 10 \mathrm{~mL} \mathrm{KCl} 0.1 \mathrm{~N}$ were added. The strong current was measured using a voltameter and analyzed using the OriginPro 7.0 program. The result was put into the linear regression equation of the standard solution of chromium (III), and chromium (III) was obtained in the urine of mice.

\section{RESULTS AND DISCUSSION}

Black rice yeast is a grown yeast in a black rice medium. Black rice is known for its nutrients including fiber, protein, vitamins, and minerals that are beneficial for human health. This material has a black pigment known as anthocyanin and can act as an antioxidant. ${ }^{1,14}$ Antioxidants are compounds that can ward off free radicals in the body and increase the metabolic pathways of fructose. ${ }^{1,15}$ These compounds are also known to inhibit the development of cancer cells in mice affected by carcinogenesis ${ }^{16}$, which is done by destroying essential enzymes oxidatively, cells, and tissues. Several types of research have shown that anthocyanins act as anti-hypertension, anti-cancer, prevention of memory loss (neuroprotectant), anti-mutagenic, anti-cataract, anti-arthritis, anti-infertility, anti-microbial, prevention of liver dysfunction, and anti-obesity which is caused by an oxidation process that occurs continuously in the body, causing cell damage or uncontrolled cell growth to become lipid peroxide or malondialdehyde 
(MDA) which leads to cell death in various body tissues. ${ }^{17}$ Anthocyanins have some functions that can inhibit the development of chronic inflammatory proliferative disease (CIPD) ${ }^{18}$, improve circulation of blood, inhibit the damage of tissue, decrease cholesterol and levels of blood sugar ${ }^{1,19,20}$, affect the function of the pituitary gland. ${ }^{1,21}$ Numerous studies have shown compounds in black rice can increase HDL levels ${ }^{1,14}$, a decrease of low-density lipoprotein (LDL), improve lipid profiles, help fight heart disease and prevent diabetes in humans. ${ }^{1,15}$ The fermentation process of black rice uses yeast grown in black rice and then extracted to produce the yeast-BR extract. The yeast fermentation process in black rice can affect its bioactive components, including an increase in cytotoxin activity and a decrease in antioxidant activity. ${ }^{1,2}$ Yeast grown in black rice medium and extracted is known as black rice yeast (yeast-BR) and is known to contain chromium. This black rice yeast has the potential to be anti-DM, which increases tolerance of blood glucose.

This study examined the physiological effects of mice (Mus musculus) that were exposed to type 2 diabetes, which was characterized by a decrease in glucose levels by administering the yeast-BR extract. This extract was known for its good nutrition: chromium (III) of $0.0113 \%$, protein $40.19 \%$, crude fiber $6.00 \%$, and starch of $5.424 \% .{ }^{22}$ Yeast that was grown in black rice is also known to be rich in anthocyanins, a compound that acts as an antioxidant. In this study, mice were given commercial food every day for 1 week for adaptation, then obesity was induced by feeding high fat and fructose. The results of the observation after 10 days show that the mice indicated type 2 diabetes mellitus (blood glucose level / BGL $\geq 150 \mathrm{mg} / \mathrm{dL}$ ) were then given yeast-BR feed using a feeding tube in addition to commercial feed. Comparison using normal mice (not indicated DM) as control of normal, mice indicated for type 2 diabetes were given glibenclamide as control of positive, mice indicated for type 2 diabetes were not treated as control of negative, and mice indicated for type 2 diabetes were treated with yeastfeed. BR. Table 1 shows the results of BGL measurements after 10 days of treatment.

Table-1: Mice BGL with the Test Material

\begin{tabular}{c|c|c|c|c}
\hline No. & Treatment & $\begin{array}{c}\text { BGL before } \\
\text { Treatment (mg/dL) }\end{array}$ & $\begin{array}{c}\text { BGL after } \\
\text { Treatment (mg/dL) }\end{array}$ & $\begin{array}{c}\text { Reduction of } \\
\text { BGL (mg/dL) }\end{array}$ \\
\hline 1 & DM + Black Rice & 423.5 & 160.5 & 263 \\
\hline 2 & DM + Glibenclamide (positive control) & 373.5 & 151 & 222.5 \\
\hline 3 & DM (negative control) & 196 & 140 & 56 \\
\hline 4 & Non-DM (normal control) & 123 & 107 & 16 \\
\hline
\end{tabular}

Information: All groups were given commercial feed

Table-1 shows that treatment with black rice yeast was able to reduce the largest BGL by $263 \mathrm{mg} / \mathrm{dl}$. This study also studied the relationship between decreased BGL and the levels of chromium absorbed by the small intestine of mice. Table- 2 shows the results of measurement on urine volume, water intake, water absorbed, the number of feces, and food absorbed during treatment.

Table-2: The Results of Reduction in BGL before and after Treatment with the Test Material, Urine Volume, Water Intake, Absorbed Water, the Amount of Feces, and the Absorbed Diet

\begin{tabular}{c|c|c|c|c|c|c}
\hline Treatment & $\begin{array}{c}\text { BGL } \\
(\mathrm{mg} / \mathrm{dL})\end{array}$ & $\begin{array}{c}\text { Urine } \\
\text { Volume } \\
(\mathrm{ml})\end{array}$ & $\begin{array}{c}\text { Water } \\
\text { Intake } \\
(\mathrm{ml})\end{array}$ & $\begin{array}{c}\text { Feces } \\
(\mathrm{gram})\end{array}$ & $\begin{array}{c}\text { Diet } \\
\text { Intake } \\
(\mathrm{gram})\end{array}$ & $\begin{array}{c}\text { Absorbed Diet } \\
(\mathrm{gram})\end{array}$ \\
\hline $\mathrm{DM}+$ Black Rice Yeast & 263 & 38.25 & 66.75 & 5.99 & 49.50 & 43.51 \\
\hline $\mathrm{DM}+$ Glibenclamide & 222.5 & 34.00 & 67.50 & 10.96 & 58.50 & 47.54 \\
\hline DM & 56 & 9.00 & 39.00 & 11.96 & 48.25 & 36.29 \\
\hline Non-DM & 16 & 10.90 & 49.60 & 9.85 & 58.50 & 48.65 \\
\hline
\end{tabular}

Information:

-All groups were given commercial feed

- Obesity induction was done for 10 days, giving treatment with the material test for 10 days

- Absorbed diet: fecal intake diet.

Table- 2 shows the data obtained from the treatment that can reduce the greatest BGL is yeast BR treatment, which is $263 \mathrm{mg} / \mathrm{dL}$. The largest volume of urine was produced by the yeast-BR treatment. 
RASĀYAN J. Chem.

Vol. 14 | No. 3 |1507-1513| July - September | 2021

Water intake the yeast-BR treatment is almost the same as glibenclamide. Table-2 shows that there is a relationship between decreased BGL levels in mice with urine volume and water intake. This can be explained that yeast-BR has a high fiber content (6\%). Fiber can slow the absorption of glucose from the small intestine into the blood in people with type 2 DM. ${ }^{23}$ The decrease of insulin activity results in the decreased transfer of glucose from plasma into cells. This will stimulate the body in the process of glycogenolysis, gluconeogenesis, and lipolysis which produce ketone bodies. The metabolic process of glucose from food is disturbed so that glucose collects in the blood (hyperglycemia) and is secreted into the urine (glycosuria) and causes osmotic diuresis, thereby increasing urine production (polyuria). Fluid loss and hyperglycemia increase plasma osmolarity which stimulates the thirst center (polydipsia). ${ }^{24}$ Homeostasis or maintaining the balance of the body in the kidneys includes acid-base balance, maintaining plasma volume, blood pressure, $\mathrm{Na}^{+}, \mathrm{H}_{2} \mathrm{O}$, maintaining osmolarity. The kidneys also maintain body balance due to filtration, secretion, excretion and reabsorption of urine. The homeostasis mechanism in the kidney involves ions, hormones, substances and enzymes in the process. ${ }^{25}$ Several studies have shown that type II diabetes can be reduced by consuming chromium (III), an essential mineral for carbohydrate metabolism in the body's cells. ${ }^{5}$ The results of $\mathrm{Cr}$ (III) measurement in mice feces are shown in Table-3.

Table-3: Measurement Data of Cr (III) in Mice Feces in Several Treatments

\begin{tabular}{c|c|c}
\hline Treatment & Netto $($ gram $)$ & Cr (III) in Feces $(\mathrm{ppm})$ \\
\hline DM + black rice yeast & 2.317 & 310.15 \\
\hline DM + Glibenclamide & 0.577 & 343.91 \\
\hline DM & 0.916 & 212.79 \\
\hline Non-DM & 2.370 & 76.66 \\
\hline
\end{tabular}

Data on Cr (III) content in the total diet intake is presented in Table-4.

Table-4: Cr (III) Content in the Total Diet Intake

Information:

\begin{tabular}{c|c|c|c}
\hline \multicolumn{2}{c}{ Table-4: Cr (III) Content in the Total Diet Intake } \\
\hline Treatment & $\begin{array}{c}\text { Cr (III) in Dietary } \\
\text { Intake, Commercial } \\
\text { Feed }\end{array}$ & $\begin{array}{c}\text { Cr (III) in Diet } \\
\text { Intake, Feeding } \\
\text { Tube (Yeast-BR) }\end{array}$ & $\begin{array}{c}\text { Cr (III) in Total } \\
\text { Dietary Intake } \\
\text { (ppm) }\end{array}$ \\
\hline DM + black rice yeast & 961.266 & 236.200 & 1197.466 \\
\hline DM + Glibenclamide & 899.745 & 0.000 & 899.745 \\
\hline DM & 742.097 & 0.000 & 742.097 \\
\hline Non-DM & 904.359 & 0.000 & 904.359 \\
\hline
\end{tabular}

- All groups were given commercial feed

- $\mathrm{Cr}$ (III) in total diet intake $=\mathrm{Cr}$ (III) in dietary intake, commercial feed $+\mathrm{Cr}$ (III) in dietary intake, feeding tube (yeast-BR).

Table- 5 shows the chromium data in the dietary intake in mice feces as well as absorbed chromium.

Table-5: Chromium in Diet Intake and Mice Feces and Absorbed Chromium

\begin{tabular}{c|c|c|c|c}
\hline Treatment & $\begin{array}{c}\text { Cr (III) in Total } \\
\text { Dietary Intake }\end{array}$ & $\begin{array}{c}\text { Cr (III) in } \\
\text { Feces (ppm) }\end{array}$ & $\begin{array}{c}\text { Cr (III) absorbed by the } \\
\text { intestines of mice (ppm) }\end{array}$ & $\begin{array}{c}\text { \% Absorbed } \\
\text { Chromium }\end{array}$ \\
\hline DM + black rice yeast & 1197.466 & 310.15 & 887.316 & 0.89 \\
\hline DM + Glibenclamide & 899.745 & 343.91 & 555.835 & 0.56 \\
\hline DM & 742.097 & 212.79 & 529.307 & 0.53 \\
\hline Non-DM & 904.359 & 76.66 & 827.699 & 0.83 \\
\hline
\end{tabular}

Information:

- All groups were given commercial feed

- $\mathrm{Cr}$ (III) absorbed by the intestines of mice (ppm) $=\mathrm{Cr}$ (III) in the total diet intake - Cr (III) in feces

Table-5 shows that the highest absorption of chromium in the intestines of mice was in the yeast-BR treatment, which was $887.316 \mathrm{ppm}(0.089 \%)$. The absorption percentage of chromium by the small intestine in this study was smaller than humans, which ranges from 0.1 to $5.2 \%$ and it depends on the 
RASĀYAN J. Chem.

Vol. 14 | No. 3 |1507-1513| July - September | 2021

chromium complex being digested. ${ }^{26}$ The most active site for chromium (III) absorption in mice is the jejenum and less efficient in the ileum and duodenum. ${ }^{27}$ Table- 6 shows the relationship between mice BGL and absorbed chromium by the small intestine.

Table-6: Relationship between mice BGL and absorbed Chromium through the Intestine

\begin{tabular}{c|c|c|c|c|c}
\hline Treatment & $\begin{array}{c}\text { BGLbefore } \\
\text { Treatment } \\
(\mathrm{mg} / \mathrm{dL})\end{array}$ & $\begin{array}{c}\text { BGLafter } \\
\text { Treatment } \\
(\mathrm{mg} / \mathrm{dL})\end{array}$ & $\begin{array}{c}\text { Reduction } \\
\text { of BGL } \\
(\mathrm{mg} / \mathrm{dL})\end{array}$ & $\begin{array}{c}\text { Chromium were } \\
\text { absorbed by the mice } \\
\text { intestines (ppm) }\end{array}$ & $\begin{array}{c}\text { \% Absorbed } \\
\text { Chromium }\end{array}$ \\
\hline $\mathrm{DM}+$ Black Rice Yeast & 423.5 & 160.5 & 263 & 887.316 & 0.089 \\
\hline $\mathrm{DM}+$ Glibenclamide & 373.5 & 151 & 222.5 & 555.835 & 0.056 \\
\hline DM & 196 & 140 & 56 & 529.307 & 0.053 \\
\hline Non-DM & 123 & 107 & 16 & 827.699 & 0.083 \\
\hline
\end{tabular}

Table-6 shows that the highest reduction in BGL and the highest absorbed chromium (Cr (III)) was treated with yeast-BR. Chromium (Cr (III)) absorbed in the yeast-BR treatment was $887.316 \mathrm{ppm}$ $(0.089 \%)$ and the decrease in BGL of mice was $263 \mathrm{mg} / \mathrm{dL}$. The reduction in BGL with yeast-BR treatment was greater when compared to controls of positive and negative. This is following chromium's role in helping insulin to bind to receptors on cells and insulin signaling pathways in glucose metabolism in walking cells. ${ }^{28}$ The levels of chromium absorbed by DM mice by administering glibenclamide were almost the same as DM mice, but the reduction in BGL of DM mice with glibenclamide was much higher when compared to DM mice without glibenclamide. This indicates that the physiological effect of glibenclamide is not directly related to the role of chromium in reducing BGL in mice. Glibenclamide or glyburide affects the pancreas to produce insulin without affecting peripheral insulin sensitivity. ${ }^{29}$ This mechanism relies on pancreatic beta cells. Sulfonylureas attach to specific receptors on pancreatic beta cells and inhibit potassium entry via ATP-dependent channels. This activity will affect the increase in calcium in $\beta$-pancreatic cells and actomyosin filaments to contract; this will trigger the insulin exocytosis process. This insulin secretion does not depend on sugar levels, so it can cause hypoglycemia. Normal control shows a small decrease in BGL even though the intestinal absorption of chromium was high when compared to negative and positive controls, namely $0.083 \%$. It can be said that glucose metabolism in non-DM mice is stable and does not depend entirely on the amount of chromium absorbed by the small intestine. This study has not been able to reveal the physiological effects of chromium on the non-DM mice in controlling the stability of BGL.

From the data obtained it can be concluded that:

\section{CONCLUSION}

1. The highest reduction in BGL was treated with DM + yeast-BR;

2. The largest volume of drinking water and urine in the DM + yeast-BR group;

3. The diet absorbed by the DM + yeast-BR group was lower than the non-DM and DM + glibenclamide, but higher than the DM group;

4. The largest percentage of chromium absorbed by the small intestine was in the DM + yeast-BR group, and

5. There was a relationship between the decrease in BGL and the $\%$ absorbed chromium in the DM + yeast-BR group, but there was no relationship between the reduction in BGL and \% of chromium absorbed in the Non-DM. This study has not been able to reveal the physiological effects of chromium on the non-DM mice in controlling the stability of BGL.

\section{ACKNOWLEDGEMENT}

Thanks to the Directorate of Research and Community Service (DRPM) through Rector of Universitas Negeri Surabaya for providing financial support for this research.

\section{REFERENCES}

1. U. K. S. Kushwaha, Black Rice: Research, History and Development, Springer International Publishing, Switzerland, p.21, 22(2016), https://doi.org/10.1007/978-3-319-30153-2

2. H. J. Yoon, K.A. Lee, J.H. Lee, H.J. Jin, H.J. Kim, K.-T. Kim and H.-D. Paik, International journal of Food Science, 50(3), 612(2014), https://doi.org/10.1111/ijfs.12693

1512 
3. B. Giri, S. Dey, T.Das, M. Sarkar, J.Banerjee and S.K. Dash, Biomedicine \& Pharmacotherapy, 107, 306(2018), https://doi.org/10.1016/j.biopha.2018.07.157

4. E. Rahmawati, B.Sc. Thesis, Department of Public Health Nutrition, University of Jember, Jember, Indonesia (2010).

5. B. E. Wilson and A. Gondy, Diabetes Research and Clinical Practice, 28(3), 179(1995), https://doi.org/10.1016/0168-8227(95)01097-W

6. I. Kato, J. H. Vogelman, V. Dilman, J. Karkoszka, K. Frenkel, N.P. Durr, N. Orentreich and P. Toniolo, European Journal of Epidemiology, 14, 621(1998).

7. R. A. Anderson, Journal of the American College of Nutrition, 17(6), 548(1998), https://doi.org/10.1080/07315724.1998.10718802

8. C. L. Broadhurst and P. Domenico, Diabetes Technology \& Therapeutics, 8(6), 677(2006), https://doi.org/10.1089/dia.2006.8.677

9. P. Trumbo, A. A. Yates, S. Schlicker and M. Poos, Journal of The American Dietetic Association, 101(3), 294(2001), https://doi.org/10.1016/S0002-8223(01)00078-5

10. W. T. Cefalu and F.B. Hu, Diabetes Care, 27, 11(2004), https://doi.org/10.2337/diacare.27.11.2741

11. C. M. Davis, K. H. Sumrall and J. B. Vincent, Biochemistry, 35, 12963(1996), https://doi.org/10.1021/bi960328y

12. R. Agustini, I. G. M Sanjaya, A. Sabarudin and A. Widodo, Rasayan Journal of Chemistry, 12(4), 2348(2019), https://doi.org/10.31788/RJC.2019.1245411

13. E. Yulianto and P. Setiarso, UNESA Journal of Chemistry, 3(3), 60(2014).

14. Y. Qin, M. Xia, J. Ma, Y. T. J. Liu, H. Y. Mou, L. Cao and W. H. Ling, The American Journal of Chemical Nutrition, 90(3), 485(2009), https://doi.org/10.3945/Ajen.2009.27814

15. H. Guo, W. Ling, Q. Wang, C. Liu, Y. Hu, M. Xia, X. Feng and X. Xia, Plant Foods Human Nutr, 62, 1(2007), https://doi.org/10.1007/s11130-006-0031-7

16. S. Thomasset, N. Teller, H. Cai, D. Marko, D. P. Berry, W. P. Steward and A. J. Gescher, Cancer Chemotherapy Pharmacology, 64(1), 201(2009), https://doi.org/10.1007/S00280-009-0976-Y

17. M. Priska, N. Peni, L. Carvallo and Y. D. Ngapa, Cakra Kimia: Indonesian E-Journal of Applied Chemistry, 6(2), 79(2018).

18. K. Ishihara and T. Hirano, Cytokine \& Growth Factor Reviews, 13, 357(2002), https://doi.org/10.1016/s1359-6101(02)00027-8

19. V. Hirunpanich, A. Utaipat, N. P. Morales, N. Bunyapraphatsara, H. Sato and A. Herunsalee, Biological and Pharmaceutical Bulletin, 28, 481(2005), https://doi.org/10.1248/Bpb.28.481

20. A. R. Rechner, C. Kroner, Thrombosis Research Journal, 116, 327(2005), https://doi.org/10.1016/J.Thromres.2005.01.002

21. E. Butelli, L. Titta, M. Giorgio, H. Mock, A. Matros and S. Peterek, Nature Biotechnology Journal, 26, 1301(2008), https://doi.org/10.1038/Nbt.1506

22. R. Agustini, I. G. M. Sanjaya and A. Widodo, Rasayan Journal of Chemistry, 12(4), 1839(2019), https://doi.org/10.31788/RJC.2019.1245314

23. M. Asif, Journal of Education and Health Promotion, 3, 1(2014), https://doi.org/10.4103/22779531.127541

24. C. J. Thompson, S. N. Davis and P. H. Baylis, The American Journal of Physiology, 256(3), 597(1998), https://doi.org/10.1152/ajpregu.1989.256.3.r597

25. A. C. Guyton and J. E. Hall, Textbook of Medical Physiology, Elsevier Saunders, Pennsylvania, p.337, 332(2006).

26. A. Holstein, A. Plaschke and E.H. Egberts, Diabetes/Metabolism Research and Reviews, 17(6), 467(2001), https://doi.org/10.1002/dmrr.235

27. N. S. Chen, A. Tsai and I. A. Dyer, Journal of Nutrition, 103(8), 1182(1973), https://doi.org/10.1093/jn/103.8.1182

28. G. Wilcox, The Clinical Biochemist Reviews, 26(2), 19(2005).

29. A. Riefflin, U. Ayyagari, S.E. Manley, R.R. Holman and J.C. Levy, Diabetologia, 58(1), 43(2015), https://doi.org/10.1007/s00125-014-3399-1

[RJC-6173/2020] 